Int. Archs Allergy appl. Immun. 1979;59:I-V

\title{
Contents, Vol. 59, 1979
}

Vol. 59,1979

International Archives of Allergy and Applied Immunology

Founded 1950 by: D. Harley, P. Kallós, W. Löffler and F, W. Wittich

Continued by: E. A. Brown (1952-1954), W. Kaufman (1955-1967), F. Hahn (1961-1972) and

H. C. Goodman (1963-1975)

Editors-in-Chief:

R. R. A. Coombs, Cambridge L. M. Lichtenstein, Baltimore, Md.

Contributing Editors:

G. Andres, Buffalo, N.Y.

E. L.Becker, Farmington, Conn.

W. E. Brocklehurst, Windlesham

A. Cerietti, Basel

B. Diamant, Copenhagen

P. Dukor, Basel

W. P. Faulk, Charleston, S.C.

M. Feldman, Rehovot

H. Fischer, Freiburg-Zähringen

R. van Furth, Leiden

P. G. H. Gell, Birmingham

H. Gewurz, Chicago, Ill.

I. Glazer, Tel Aviv

R. A. Good, New York, N.Y.

F. Hahn, Wittnau

L. Å. Hanson, Göteborg

P. Kallós, Helsingborg F. Milg Гom, Buffalo, N.Y.

M. Hess, Bern

L. Hudson, Beckenham

H. Isliker, Lausanne

S. G. O. Johansson, Uppsala

E. A. Kabat, New York, N.Y.

K. Kano, Buffalo, N.Y.

R. Keller, Zurich

ö. Ouchterlony, Göteborg

Z. Ovary, New York, N.Y.

P. Perlmann, Stockholm

E. Pick, Tel Aviv

K. W. Pondman, Amsterdam

R. E. Reisman, Buffalo, N.Y. 
M. Roitt, London

K. Rother, Heidelberg

D. S. Rowe, Lausanne

Z. Trnka, Basel G. B. West, Epsom

H. D. Schlumberger, Wuppertal

A. Sehon, Winnipeg

E. Sorkin, Davos-Platz

H. Storck, Zurich

A. Szenberg, Melbourne

A. Szentivanyi, Tampa, Fla.

T. B. Tomasi, jr., Rochester, Minn.

G. Torrigiani, Geneve

J. L. Turk, London

E. R. Unanue, Boston, Mass.

G. A. Voisin, Paris

B.H.Waksman,

New Haven, Conn.

A. L. de Week, Bern

G. Wick, Innsbruck

S.Karger $\cdot$ Basel $\cdot$ München $\cdot$ Paris $\bullet$ London $\cdot$ New York $\cdot$ Sydney

All rights reserved.

No part of this publication may be translated into other languages, reproduced or utilized in any

form or by any means, electronic or mechanical, including photocopying, recording,

microcopying, or by any information storage and retrieval system, without permission in writing from the publisher.

S. Karger AG, 4011 Basel (Switzerland), Arnold-Böcklin-Strasse 25

Printed in Switzerland by Buchdruckerei National-Zeitung + Basler Nachrichten AG, Basel

Contents Vol. 59,1979

No.1

Original Paper

Berczi, I.; Kovács, K.; Horváth, E., and Sehon,

A. H.: Rejection of Tumor Cells in vitro:

Morphological Studies on Killer T Cells and

Damaged Tumor Cells

1

Goto, K.; Terasawa, M., and Maruyama, Y.:

Anti-Allergic Activities of a New Benzopyra-

nopyridine Derivative Y-12,141 in Rats

Baumal, R.: Similarity of Casein- and Endotoxin-

Induced, Myeloma-Associated and Aged SJL/

$\mathrm{J}$ Amyloid in Various Strains of Mice

Drach, G. and Chen-Marotel, J.: Delayed Type

Hypersensitivity to Bovine Serum Albumin

and to Lipid-Conjugated Bovine Serum Albu

min in Mice 28 
Khandwala, A.; Damiani, P., and Weinryb, I.: Antigen-Induced Release of Histamine from Passively Sensitized Guinea Pig Lung Slices. I. Optimum Conditions for in vitro Passive Sensitization and Challenge with Antigen ... 34

Richter, A. W.; Ryde, E. M., and Zetterström, E. O.: Non-Immunogenicity of a Purified Sodium Hyaluronate Preparation in Man .. 45

Wicher, V.; Olszewski, W., and Milgrom, F.:

Suppressed Lymphoblastic Response to Mye-

lin Basic Protein of Lymphocytes from Pa

tients with Multiple Sclerosis 49

Whiteside, T. L. and Manski, W. J.: Lateral and

Transmembrane Redistribution of Tissue-

Specific Antigens in Single Cells and Mono-

layers 58

Bryant, R. L. and Barnett, J. B.: Adjuvant Properties of Retinol on IgE Production in Mice 69

Hall, J.; Orlans, E.; Reynolds, J.; Dean, C.; Pep-

pard, J.; Gyure, L., and Hobbs, S.: Occur

rence of Specific Antibodies of the IgA Class

in the Bile of Rats 75

Weissberg, R. M. and Garay, G. L.: Ascaris-

Induced Respiratory Responses in the Con

scious Rhesus Monkey 85

Csaba, B. and Jusupova, S.: Effects of Disodium

Chromoglycate on Systemic Anaphylaxis in

Guinea Pigs, Rats and Mice 95

Knothe, R.; Herrlinger, J. D., and Müller-Ruch-

holtz, W.: B Cell Activity in Rat Bone Marrow

and Spleen during Primary and Secondary

Response: Dependence of Strength of Antigen 99

An, T. and White, W.: Fc Receptors on Human

Lymphocytes Detected with Double-Coating

Indirect Rosette Formation 104

Short Communications

Lee, Y.; Yoshizawa, Y.; Carr, R. G., and Yoko-

yama, M. M.: A Simpler Method for Combin

ed Detection of Human Peripheral Lympho

cyte Subpopulations 114

Cahill, R. N. P.; Poskitt, D. C; Heron, I., and

Trnka, Z.: Collection of Lymph from Single

Lymph Nodes and the Intestines of Fetal

Lambs in utero

117

No. 2

Original Paper

Homer, J. T. and Cain, W. A.: Enhancement of

IgE Antibody Formation in the Rabbit by

Adrenergic Antagonists 
Kelly, J. F.; Fish, J. E., and Peterman, V. I.:

Effect of Environmental Exposure on Bron

chial Sensitivity to Antigen 130

Ureña, V.; Garcia, R.; Vela, C; Ortiz, F., and Lahoz, C.: In vitro Production of IgE and IgG by

Sensitized Human Peripheral Lymphocytes 135

Branefors, P.: A Serological Study of Somatic

Antigens from Haemophilus influenzae and

Two Related Species 143

Branefors, P.: Cross-Reactivity of the O Antigens among Haemophilus influenzae Type b Strains 150

Stevenson R. D.; Gray, A. C, and Lucie, N. P.:

Effects of Theophylline on Capillary Tube

Leucocyte Migration 155

Ridell, M.; Baker, R.; Lind, A., and Ouchterlony,

Ö.: Immunodiffusiod Studies of Ribosomes in

Classification of Mycobacteria and Related

Taxa 162

Donner, M. and Mehrishi, J. N.: The Lymphocyte

Surface. Surface Topochemistry of Murine

Thymocytes Related to the Major Histocom-

patibility Complex 173

Contents

IV

Attallah, A.M.; Steinberg, A. D.; Ahmed, A., and Sell, K. W.: Loss of Lymphocyte Chalone

Activity in Mice with Autoimmune Disease .. 186

Blomgren, H.: Characterization of Lymphocytes

Which Inhibit Proliferation of Human T Cells

Exposed to Lymphocyte-Derived Mitogenic

Factors

192

Farris, R. L. and Manski, W.: Studies on Com

petitive Inflammatory Sites. I. Influence of the

Size of Sensitizing Skin Implants on Second-

Set Corneal Graft Reactions 199

Manski, W.; Farris, R. L., and Hofeldt, A. J.:

Studies on Competitive Inflammatory Sites.

II. Depression of Second-set Corneal Allograft

Reactions by Allogeneic and Xenogeneic Skin

Implantation 208

Nordlind, K.; Ernström, U., and Mutt, V.: L-

Alanine - an Essential Amino Acid for Growth

of Lymphocytes in vitro

215

Ogita, T.; Hayakawa, T.; Horiuchi, Y., and Mizu-

shima, Y.: Effect of Levamisole on the Auto-

Antibody Formation in Nude Mice 222

Short Communications 
Vijay, H. M.; Lavergne, G.; Huang, H., and Bern

stein, I. L.: Preferential Synthesis of IgE Re-

aginic Antibodies in Rats Immunized with

Alum-Adsorbed Antigens 227

Ring, J.: Atopic Dermatitis: A Disease of General

Vasoactive Mediator Dysregulation 233

Book Reviews $\quad 240$

No. 3

Original Paper

Umeda, T.; Niijima, T.; Tanino, T.; Saito, M., and Egawa, K.: Agglutination of Murine Tu

mor Cells by Sera from Patients with Auto

immune Diseases 241

Di Prisco-de-Fuenmayor, M. C.: Fc Receptors

for Human, Rabbit and Pig Antibodies on

Human Eosinophils from Normal Persons

and Patients with Atopic Dermatitis 249

Barnett, J. M. and Glick, B.: Effect of Complement Inactivated Rabbit Antichick Brain Serum on Thymic and Splenic Lymphocytes ... 256

Hicks, R.; Hewitt, P. J., and Lam, H. F.: An Investigation of the Experimental Induction of

Hypersensitivity in the Guinea Pig by Material

Containing Chromium, Nickel and Cobalt

from Arc Welding Fumes 265

Kelly, R. H. and Harvey, V. S.: Lymphocyte

Migratory Pathways in Adjuvant Disease.

II. Distribution of Thoracic Duct Lymph-

Borne Immunoblasts 273

Miller, H. R. P.; Nawa, Y., and Parish, C. R.: Intestinal Goblet Cell Differentiation in Nippostrongylus-Intectcd Rats after Transfer of Fractionated Thoracic Duct Lymphocytes .. 281

Malcolm, A. J.; Holford-Strevens, V., and Sehon, A. H.: The Effect of Hapten-Specific

Suppression of IgE on Antigen-Induced Histamine Release from Mouse Peritoneal Mast Cells .. 286

Assoku, R. G. K.; Hazlett, C. A., and Tizard, I.:

Immunosuppression in Experimental African

Trypanosomiasis. Polyclonal B-Cell Activa

tion and Mitogenicity of Trypanosome-Deriv-

ed Saturated Fatty Acids 298

Meroni, P. L.; Ciboddo, G. F.; Colombo, G.;

Bonara, P., and Invernizzi, F.: T Cell Defect

in Essential Mixed Cryoglobulinaemia 308

Johnson, G. R.; Nicholas, W. L.; Metcalf, D.; McKenzie, I. F. C, and Mitchell, G. F.: Peritoneal

Cell Population of Mice Infected with Mesocestoides corti as a Source of Eosinophils 315

De Cueninck, B. J.: C142 Complement Activity

and Conglutinogen in Bovine Milk 323

Baker, R.; Ridell, M.; Lind, A., and Ouchterlony,

ö.: Immunodiffusion Studies of Various 
Structural Preparations from Mycobacterial

Cells 328

Iannelli, D.: Rhesus Monkey (Macaca mulatto)

Allotypes. Identification of Three Low Density

Lipoprotein Allotypes Controlled by Inde

pendent Genes 337

Walker, J. R.; Smith, M. J. H., and James, D. W.:

A Comparison of Two in vitro Methods for

Studying a Defect in Leucocyte Movement in

Rheumatoid Arthritis 343

Zolla-Pazner, S.; Koehne, C, and Oratz, R.:

Humoral Mediator of Antigenic Competition

Demonstrated in vivo 349

Short Communication

Tranter, B. C. and West, G. B.: Effects of Levamisole and D-Penicillamine in Rat Paw Oedema Induced by Carrageenan and by Kaolin .357

Contents

$\mathrm{V}$

No. 4

Original Paper

Kasahara, T.; Kin, K.; Itoh, Y.; Kawai, T.; Ka-

no, Y., and Shioiri-Nakano, K.: Cellular Co

operation in Lymphocyte Activation. III. B-

Cell Helper Effect in the Enhancement of T-

Cell Response 361

Yoshida, T.; Mikawa, H.; Shinomiya, K.; Hirao,

T., and Okuda, R.: Interaction among IgE-

Mediated Hypersensitivity Reaction, PCA

Reaction and Delayed Hypersensitivity Reac

tion (at Local Skin Sites of Monkeys)

Li Hsü, S. Y.; Hsü, H. F.; Penick, G. D.; Han

son, H. O.; Schiller, H. J., and Cheng, H. F.:

Immunoglobulin E, Mast Cells, and Eosino-

phils in the Skin of Rhesus Monkeys Immuniz

ed with X-Irradiated Cercariae of Schistosoma

japonicum 383

De Cueninck, B. J.: Immune-Mediated Inflamma

tion in the Lumen of the Bovine Mammary

Gland 394

Ishikawa, T.; Shimada, T.; Kessoku, N., and

Kiyoi, M.: Inhibition of Rat Mast Cell Degra-

nulation and Histamine Release by Histamine-

Rat Gammaglobulin Conjugate 403

Oka, S.; Suzuki, H.; Jyo, T., and Tsuji, M.: Purification of Two Types of Sea-Squirt Antigens 408 
Charlesworth, J. A.; Quin, J. W.; Holloway, R. H.; Jones, B. F., and Robertson, M. R.: Im pairment of Acute Phase Protein Reactivity in Chronic Renal Failure 420

Mancino, D. and Bevilacqua, N. (Naples): Fur ther Studies on the Adjuvant Effect of Silica on IgE Antibody Production in Mice 427 Meade, C. J.: How Arachidonic Acid Depresses Thymus Weight 432

Sharpe, T. J.; Harling, E. J., and Smith, H.: Acute Inflammation Following Intraperitoneaî Injection of Antigen into Actively Sensitised Rats 437 Eyre, P. and Deline, T. R.: Cholinergic Modula tion of Anaphylactic Dopamine Release from Calf Lung 443

Sindo, T.; Haga, K.; Yamamoto, Y.; Hayashi, Y., and Ozawa, K.: Studies on the Interference between the Allergic Reactions Caused by Different Antigen-Antibody Systems 447 Megel, H. and Denney, D. L.: Systemic Persis tence of Homologous Guinea Pig Skin-Sensi tizing Antibodies 452 Penner, E.; Emejuaiwe, S. O., and Milgrom, F.: Detection of a Microsomal Antigen and Its Antibody in Human Liver Diseases 459 Short Communication

Scaglia, M.; Tinelli, M.; Revoltella, R.; Peracino, A.; Falagiani, P.; Jayakar, S. D.; Desmarais, J. C, and Siccardi, A. G.: Relationship be tween Serum IgE Levels and Intestinal Para site Load in African Populations 465 Book Reviews $\quad 469$

Author Index 473 